\title{
Outlook on disease resistant grapevine varieties
}

\author{
Luigi Bavaresco ${ }^{1,2^{*}}$ and Cecilia Squeri ${ }^{1}$ \\ ${ }^{1}$ DI.PRO.VE.S. Viticulture and Pomology section, Università Cattolica del Sacro Cuore, 29122 Piacenza, Italy \\ ${ }^{2}$ Centro di Ricerca sulla Biodiversità e sul DNA antico, Università Cattolica del Sacro Cuore, 29122 Piacenza, Italy
}

\begin{abstract}
Breeding programs for disease resistance were developed from the 19th century on, in both the old (Europe) and new world as a way to promote sustainable viticulture. The main results of breeding, in terms of disease resistance and grape (and wine) quality are described, ranging from the first American hybrids to the most recent varieties. The activity of some representative breeders is discussed and the current situation in Italy is reported. Productive, legislative, and commercial aspects for wine production are considered, especially for European Union where the wine sector is strongly regulated. The perspectives of breeding for disease resistance are discussed, including the new breeding techniques (Nbt) like cis-genesis and genome editing. The importance to interact with the society to make acceptable these innovations is emphasized. While less acceptance problems are expected with table grapes, raisins or rootstocks, more concerns might arise with wine grapes. The role of science is to give the legislator tools to cope with sustainability and to educate the society (from the grape grower to the wine consumer) to a correct understanding. Innovations can be a real advantage only if they are accepted by all the actors of the wine chain.
\end{abstract}

\section{Introduction}

There are many strategies to reduce pesticide impact in viticulture (while controlling pests and diseases) like the biocontrol, the use of containment sprayers and epidemiological models, the stimulation of the natural defense mechanisms by abiotic elicitors. These are anyway actions to be used every year, partially solving the problem, but allowing to grow the traditional wine grape varieties.

Long-term strategies to reduce spray treatments rely on the choice of proper terroirs and proper cultural practices and on breeding. The latter is the most powerful tool and includes clonal selection (poor impact, mostly toward grey mould), intra- and inter-specific controlled hybridization, and new breeding techniques (Nbt) like cisgenesis and genome editing.

To rely on breeding means to promote resilience instead of managing risks; resilience is the best way to minimize impacts from adverse events, aiming at longterm security [1]. On the other hand, risk management aims for short-term security, requires direct intervention and needs continuous monitoring.

Nowadays the only available disease resistant vines have been produced by inter-specific controlled crosses. The idea to combine in one individual the disease resistance traits of wild species with the fruit (and wine) quality traits of $V$. vinifera, in order to get the ideal vine, can be traced back to the $19^{\text {th }}$ century when American and European breeders began this adventure for different contingent events. In USA the attempts to grow $V$. vinifera varieties failed due to the susceptibility to downy and powdery mildew and to phylloxera; the solution to get grapes for wine making was to rely on the native species (V. labrusca, aestivalis, rotundifolia, etc.) or to cross them with $V$. vinifera [2]. Moreover, the American breeders combined together wild species like $V$. labrusca, $V$. riparia, V. aestivalis, etc. [3]. The results include a group of own-rooted varieties termed American hybrids (Clinton, Noah, Niagara, Jaquez, Catawba, Isabella, etc), showing good resistance but bad quality. In Europe the traditional way to grow $V$. vinifera varieties without any protection program collapsed when the two fungi (downy and powdery mildews) and the insect (phylloxera) arrived in the vineyards. One of the solutions was first the use of the American hybrids and then another hybridization program which was mainly developed in France with unsatisfactory results because, despite the resistance, the wine quality was very poor.

These hybrids had anyway a strong impact on the French wine system, reaching in the ' $50 \mathrm{~s}$ of the $20^{\text {th }}$ century about 400,000 ha (about $30 \%$ of the French bearing area) and flooding the market with a huge volume of bulk wine [4]. Afterwards the acreage of these French hybrids decreased also due to the effects of European regulations [5], and in 2018 the French bearing area was about 3,500 ha. Later on, breeding programs developed in many European, Asiatic and American countries produced new individuals with an improved level of grape (and wine) quality and in some cases a vinifera-like wine [6-9].

\footnotetext{
* Corresponding author: luigi.bavaresco@unicatt.it
} 


\section{Important breeders}

Many breeders all over the world (especially in USA and Europe) worked on this subject producing an amazing number of hybrids. Among the pioneers, we can mention T.V. Munson, an American scholar who wrote a book (Foundations of American Grape Culture, 1909) where he lists the personal qualifications necessary in the originator, as follows: theoretical and personal knowledge; experience; skills; inventive faculty; patience and perseverance; no stimulus of money-making; enthusiasm; ambition; intense love of close communion with nature; discover the great fundamental truth in ethics. The following philosophical sentence closes the list: love breeds life; hate breeds death.

Among the recent breeders, we would like to mention G. Alleweldt, H.P. Olmo, M.A. Walker, A. Bouquet, Shao Hua Li, E. Peterlunger, R. Testolin, and M. Stefanini.

G. Alleweldt (1927 - 2005) was for a long time the Director of the former BFA für Rebenzüchtung Geilweilerhof (nowadays JKI), at Siebeldingen (Rheinland Pfalz, Germany), a research institute devoted only to grapevine breeding for disease resistance, where he released many new disease resistant varieties, like Regent (Diana x Chambourcin), Orion (Optima x Villard blanc), Sirius (Bacchus x Villar blanc), etc. He also was professor of Viticulture by Hohenheim Universität at Stuttgart, he was involved in the integration of the former DDR research institutes after the Germany reunification in 1990; moreover he set up the Vitis International Variety Catalogue (VIVC, the inventory of Vitis species, varieties and other Vitis genotypes existing in the grapevine collections world-wide), which is still run by JKI.

H.P. Olmo (1909 - 2006) as a professor by UC Davis (California, USA) was a prolific breeder and a Vitis germplasm collector. He released many table, raisins and wine grape varieties, including an interesting hybrid (Rubired= Alicante Ganzin x Tinta Cao) which covers about 4,800 ha in USA [10].

M.A. Walker (UC Davis) represents the next generation (after Olmo) and like his predecessor is a germplasm collector and a rootstock and fruiting vine breeder; he has just released (in 2019) five new Pierce's disease resistant varieties utilizing as resistance source $V$. arizonica (Table 1).

In France a pivotal role was played by Alain Bouquet (1948 - 2009) who introduced in the breeding programs Vitis rotundifolia, together with $V$. vinifera; his varieties have been utilized by other breeders of INRAE Colmar to produce new disease resistant varieties (listed in the French Ampelographic Register), as follows: Artaban and Vidoc (red wine grape cvs.); Floréal and Voltis (white wine grape cvs.); Rebelia (red juice cv.); Reclia and Recybel (white juice cvs.). These varieties are the result of the Resdur program, being introduced 2 genes of downy and powdery mildew resistance.

In China an important breeder is Shao Hua $\mathrm{Li}$ (University of Chinese Academy of Sciences) who released many varieties of local interest and also organized the XI International Conference on Grapevine Breeding and Genetics in 2014.
Table 1. Pierce's disease (PD) resistant varieties (released by M.A. Walker, UC Davis, 2019).

\begin{tabular}{|c|c|c|c|}
\hline Name & Crossing & $\begin{array}{l}\text { Vinifera } \\
\text { pedigree }\end{array}$ & $\begin{array}{c}\text { Wine } \\
\text { description }\end{array}$ \\
\hline $\begin{array}{l}\text { Camminar } \\
\text { e Noir }\end{array}$ & $\begin{array}{l}V . \text { arizonica } \\
\mathrm{x} V \text {. vinifera }\end{array}$ & $\begin{array}{c}\text { Petite Syrah, } \\
\text { Cabernet } \\
\text { Sauvignon, } \\
\text { etc.; } 94 \% \\
\text { vinifera }\end{array}$ & $\begin{array}{l}\text { Dark red- } \\
\text { purple, } \\
\text { bright red } \\
\text { fruit, } \\
\text { raspberry, } \\
\text { cherry, } \\
\text { tannic and } \\
\text { elegant } \\
\text { rather than } \\
\text { dense }\end{array}$ \\
\hline $\begin{array}{c}\text { Paseante } \\
\text { Noir }\end{array}$ & $\begin{array}{l}V . \text { arizonica } \\
\mathrm{x} \text { V. vinifera }\end{array}$ & $\begin{array}{c}\text { Zinfandel, } \\
\text { Petite Syrah, } \\
\text { Cab. } \\
\text { Sauvignon, } \\
\text { etc.; } 97 \% \\
\text { vinifera }\end{array}$ & $\begin{array}{c}\text { Medium- } \\
\text { dark red, } \\
\text { berry pie, } \\
\text { cassis, black } \\
\text { olive, herbal, } \\
\text { dried hay, } \\
\text { coffee, } \\
\text { vegetal, } \\
\text { licorice, } \\
\text { moderate } \\
\text { tannins }\end{array}$ \\
\hline $\begin{array}{c}\text { Errante } \\
\text { Noir }\end{array}$ & $\begin{array}{l}\text { V. arizonica } \\
\mathrm{x} \text { V. vinifera }\end{array}$ & $\begin{array}{l}\text { Sylvaner, } \\
\text { Cab. } \\
\text { Sauvignon, } \\
\text { Carignan, } \\
\text { Chardonnay, } \\
\text { etc.; } 97 \% \\
\text { vinifera }\end{array}$ & $\begin{array}{c}\text { Dark red } \\
\text { purple, } \\
\text { complex } \\
\text { fruit, herbs, } \\
\text { earth, plum, } \\
\text { dense, tannic } \\
\text { but balanced }\end{array}$ \\
\hline $\begin{array}{l}\text { Ambulo } \\
\text { Blanc }\end{array}$ & $\begin{array}{l}V . \text { arizonica } \\
\mathrm{x} \text { V. vinifera }\end{array}$ & $\begin{array}{c}\text { Cab. } \\
\text { Sauvignon, } \\
\text { Carignan, } \\
\text { Chardonnay, } \\
\text { etc.; } 97 \% \\
\text { vinifera }\end{array}$ & $\begin{array}{l}\text { Light straw, } \\
\text { citrus, lime, } \\
\text { tropical, } \\
\text { gooseberry, } \\
\text { apple, bright } \\
\text { fruit, slightly } \\
\text { bitter, } \\
\text { textured }\end{array}$ \\
\hline $\begin{array}{c}\text { Caminante } \\
\text { Blanc }\end{array}$ & $\begin{array}{l}\text { V. arizonica } \\
\mathrm{x} V \text {. vinifera }\end{array}$ & $\begin{array}{c}\text { Cab. } \\
\text { Sauvignon, } \\
\text { Chardonnay, } \\
\text { Carignan, } \\
\text { etc.; } 97 \% \\
\text { vinifera }\end{array}$ & $\begin{array}{l}\text { Light straw- } \\
\text { gold, floral } \\
\text { aromas, } \\
\text { apple-melon, } \\
\text { lychee, } \\
\text { pineapple, } \\
\text { green apple, } \\
\text { juicy, well- } \\
\text { balanced }\end{array}$ \\
\hline
\end{tabular}

In Italy the first breeding programs were developed by E. Peterlunger and R. Testolin (University of Udine) who released 14 new disease resistant varieties (Table 2; all listed in the National Ampelographic Register), and recently also M. Stefanini (FEM, San Michele all'Adige) registered 4 new individuals (Table 3 ).

Other programs are on the pipeline all over the world [11-13], like for instance the one run by CREA VE, Conegliano (Italy) which was initiated by L. Bavaresco in 2012, aiming at improving the disease resistance of $V$. vinifera cvs. Glera and Raboso Piave by controlled interspecific hybridization. 
Table 2. Disease resistant varieties obtained by university of Udine and listed in the Italian ampelographic register.

\begin{tabular}{|c|c|c|}
\hline Name & Color & Registration date \\
\hline Cabernet Eidos & Red & GU $19928 / 8 / 2015$ \\
\hline Cabernet Volos & Red & GU $19928 / 8 / 2015$ \\
\hline Fleurtai & White & GU $1036 / 5 / 2015$ \\
\hline Julius & Red & GU 103 6/5/2015 \\
\hline Merlot Kanthus & Red & GU $19928 / 8 / 2015$ \\
\hline Merlot Khorus & Red & GU $19928 / 8 / 2015$ \\
\hline Sauvignon & White & GU $19928 / 8 / 2015$ \\
\hline Kretos & White & GU $19928 / 8 / 2015$ \\
\hline Sauvignon Nepis & White & GU $19928 / 8 / 2015$ \\
\hline Sauvignon Rytos & White & GU 103 6/5/2015 \\
\hline Sorèli & White & GU $15217 / 6 / 2020$ \\
\hline Kersus & White & GU $15217 / 6 / 2020$ \\
\hline Pinot Iskra & Red & GU $15217 / 6 / 2020$ \\
\hline Pinot Kors & Red & GU $15217 / 6 / 2020$ \\
\hline Volturnis & & \\
\hline
\end{tabular}

Table 3. Disease resistant varieties from FEM S. Michele all 'Adige and listed in the Italian ampelographic register.

\begin{tabular}{|c|c|c|}
\hline Name & Color & Registration date \\
\hline $\begin{array}{c}\text { Termantis } \\
\text { (F22p09) }\end{array}$ & Red & GU 152 17/6/2020 \\
\hline $\begin{array}{c}\text { Nermantis } \\
\text { (F22p10) }\end{array}$ & Red & GU 152 17/6/2020 \\
\hline Charvir (F23p65) & White & GU 152 17/6/2020 \\
\hline Valnosia (F26p92) & White & GU 152 17/6/2020 \\
\hline
\end{tabular}

\section{Hybrids in the world}

Nowadays, about $6 \%$ of the world viticultural area is covered by hybrids and the most grown is Kyoho (with $V$. labrusca and $V$. vinifera in the pedigree), a Japanese tetraploid table grape variety present in China $(365,000$ ha, OIV data). The wine grape hybrids are mainly spread in America and Europe. According to Anderson and Nelgen [10] the countries growing large acreages of hybrids are: Brasil; USA; Moldova; Russia; Hungary; Canada.

The most grown varieties in the above-mentioned countries are listed below:

- Brasil: Isabella (11,664 ha, 35\% national share wine grapes); Couderc noir (1,938 ha, 6\%); Concord (1,687 ha, $5 \%)$, Niagara (1,430 ha, 4\%); Jacquez (1,274 ha, $4 \%)$.
- USA: Concord (8,349 ha, 3.5\%); Rubired (4,825 ha, $2 \%)$; Niagara (1,196 ha, $0.5 \%)$; Catawba (625 ha, $0.3 \%)$.

- Moldova: Moldova (12,375 ha, $15 \%)$; Isabella (3,468 ha, $4 \%)$; Bianca (1,340 ha, $2 \%)$.

- Russia: Bianca (3,513 ha, 7\%); Pervenest Magaracha (2,238 ha, 4\%); Isabella (1,362 ha, 3\%); Dunavsky Lazur (483 ha, 1\%).

- Hungary: Bianca (4,898 ha, $8 \%)$; Aletta (1,676 ha, $3 \%)$; Zalagyongye (1,075 ha, 2\%), Kunleany (974 ha, $1.5 \%)$.

- Canada: Seyval blanc (2,259 ha, $18 \%)$; Baco noir (704 ha, 6\%); Concord (183 ha, 1\%); Millot Foch (124 ha, 1\%); Marechal Foch (94 ha, 1\%).

Those wine grape varieties include the old American, French, Hungarian and Russian hybrids normally grown in challenging areas where $V$. vinifera can suffer from abiotic and/or biotic stresses.

The new disease resistant wine grape varieties (obtained mostly from the " 70 s on) are so far marginally grown, like for instance Regent (r) which covers about 1,991 ha in Germany.

\section{Italian situation}

In the Italian Ampelographic Register are listed 35 disease resistant varieties (Table 4) being Regent and Bronner the first ones (registered in 2009) and Palma, Ranchella, and Sevar the last ones (registered in 2021) but only a few regions classified them.

Table 4. Disease resistant varieties listed in the Italian Ampelographic Register - wine grape section (note: not allowed for PDO wines, ex art.8, comma 6, dl 61/2010).

\begin{tabular}{|c|c|c|}
\hline Name & Colour & Registration date \\
\hline Bronner & White & GU $14626 / 6 / 2009$ \\
\hline Cabernet Blanc & White & GU $15217 / 6 / 2020$ \\
\hline Cabernet Carbon & Red & GU $1869 / 8 / 2013$ \\
\hline Cabernet Cortis & Red & GU $1869 / 8 / 2013$ \\
\hline Cabernet Eidos & Red & GU $19928 / 8 / 2015$ \\
\hline Cabernet Volos & Red & GU 199 28/8/2015 \\
\hline Cabertin & Red & GU $15217 / 6 / 2020$ \\
\hline Charvir & White & GU $15217 / 6 / 2020$ \\
\hline Fleurtai & White & GU 103 6/5/2015 \\
\hline Helios & White & GU 186 9/8/2013 \\
\hline Johanniter & White & GU 186 9/8/2013 \\
\hline
\end{tabular}




\begin{tabular}{|c|c|c|}
\hline Julius & Red & GU 103 6/5/2015 \\
\hline Kersus & White & GU 152 17/6/2020 \\
\hline Merlot Kanthus & Red & GU 199 28/8/2015 \\
\hline Merlot Khorus & Red & GU 199 28/8/2015 \\
\hline Muscaris & White & GU 258 6/11/2014 \\
\hline Nermantis & Red & GU 152 17/6/2020 \\
\hline Palma & White & GU 43 20/2/2021 \\
\hline Pinot Iskra & White & GU 152 17/6/2020 \\
\hline Pinot Kors & Red & GU 152 17/6/2020 \\
\hline Pinot Regina & Red & GU 152 17/6/2020 \\
\hline Pinotin & Red & GU 152 17/6/2020 \\
\hline Prior & Red & GU 186 9/8/2013 \\
\hline Ranchella & Red & GU 43 20/2/2021 \\
\hline Sauvignon Kretos & White & GU 199 28/8/2015 \\
\hline Sauvignon Nepis & White & GU 199 28/8/2015 \\
\hline Sauvignon Rytos & White & GU 199 28/8/2015 \\
\hline Sevar & Red & GU 43 20/2/2021 \\
\hline Regent & Red & GU 146 26/6/2009 \\
\hline Solaris & White & GU 186 9/8/2013 \\
\hline Sorèli & White & GU 103 6/5/2015 \\
\hline Souvignier Gris & White & GU 258 6/11/2014 \\
\hline Termantis & Red & GU 152 17/6/2020 \\
\hline Valnosia & White & GU 152 17/6/2020 \\
\hline Volturnis & Red & GU 152 17/6/2020 \\
\hline
\end{tabular}

Table 5. Italian production of grafted cuttings of the new disease resistant varieties (www.politicheagricole.it).

\begin{tabular}{|c|c|c|c|c|}
\hline Varieties & 2012 & 2015 & 2016 & 2020 \\
\hline Sorèli W & $==$ & 31,200 & 113,700 & 602,975 \\
\hline $\begin{array}{l}\text { Merlot } \\
\text { Khorus R }\end{array}$ & $==$ & $==$ & 80,920 & 471,750 \\
\hline $\begin{array}{c}\text { Sauvignon } \\
\text { Rytos W }\end{array}$ & $==$ & $==$ & 108,500 & 262,700 \\
\hline Fleurtai W & $==$ & 50,050 & 141,100 & 235,350 \\
\hline $\begin{array}{c}\text { Souvignier } \\
\text { gris W }\end{array}$ & $==$ & $==$ & 60,400 & 218,005 \\
\hline $\begin{array}{l}\text { Cabernet } \\
\text { Volos R }\end{array}$ & $==$ & $==$ & 187,350 & 181,125 \\
\hline $\begin{array}{c}\text { Merlot } \\
\text { Kanthus R }\end{array}$ & $==$ & $==$ & 80,920 & 127,600 \\
\hline $\begin{array}{c}\text { Cabernet } \\
\text { Eidos R }\end{array}$ & $==$ & $==$ & 59,100 & 127,275 \\
\hline $\begin{array}{c}\text { Bronner } \\
\text { W }\end{array}$ & 17,500 & 88,500 & 55,800 & 118,253 \\
\hline Solaris W & $==$ & $==$ & 80,500 & 112,312 \\
\hline $\begin{array}{c}\text { Sauvignon } \\
\text { Kretos W }\end{array}$ & $==$ & $==$ & 141,900 & 80,175 \\
\hline $\begin{array}{c}\text { Sauvignon } \\
\text { Nepis W }\end{array}$ & $==$ & $==$ & 85,900 & 67,925 \\
\hline $\begin{array}{c}\text { Johanniter } \\
\text { W }\end{array}$ & $==$ & 28,100 & 36,000 & 44,550 \\
\hline $\begin{array}{l}\text { Cabernet } \\
\text { Blanc W }\end{array}$ & $==$ & $==$ & $==$ & 37,300 \\
\hline Prior R & $==$ & $==$ & 12,800 & 36,000 \\
\hline $\begin{array}{l}\text { Cabernet } \\
\text { Cortis R }\end{array}$ & $==$ & 8,060 & 51,700 & 33,375 \\
\hline $\begin{array}{c}\text { Muscaris } \\
\text { W }\end{array}$ & $==$ & $==$ & $==$ & 15,606 \\
\hline Julius R & $==$ & 4,100 & 3,700 & 6,040 \\
\hline Regent R & 300,000 & 2,100 & 800 & 1,700 \\
\hline TOTAL & 317,500 & $\begin{array}{c}212,110 \\
(0.1 \%)\end{array}$ & $\begin{array}{c}1,233,670 \\
(0.6 \%)\end{array}$ & $\begin{array}{c}2,780,016 \\
(1.6 \%)\end{array}$ \\
\hline
\end{tabular}

The yield grafted cuttings / rootlings is not $100 \%$ and therefore a lower number of plants is supposed to be available for vineyards establishment.

The bearing area of each variety is not yet recorded but we can speculate about a few hundred hectars (total value). Data on grafted cuttings production of Italian nurseries are available (Table 5) and the number of disease resistant varieties increased over time reaching in 2020 about $2,780,000$ (1.6\% of the Italian production). 


\section{Main traits of the new disease resistant varieties}

The main traits are as follows:

- Organoleptic characteristics of the wine: many varieties are vinifera - like, but not displaying the same sensory profile and the agronomical traits as the vinifera parent.

- Good agronomical performance.

- Disease resistance: not $100 \%$, but some spray treatments are needed.

- Need to be grown in the environment where they were obtained, or in similar ones; need of a careful assessment if grown in environments other than the original one.

- Some of those are winter hardy (where V. amurensis or $V$. riparia are present in the pedigree).

- The majority is early ripening.

\section{Legislation issues}

The cultivation of these new varieties and the commercialization of the wines is regulated only in the European Union (EU), while in the rest of the world the only ruler is the market response.

No PDO wines can be produced so far with resistant varieties, but, on this respect, the situation within the Member States is not the same.

A different behaviour of the EU countries as concerning the registration of new resistant varieties occurs. The Federal Republic of Germany, for instance, has classified them as $V$. vinifera, unlike Italy and France where they are considered as crosses between $V$. vinifera and other Vitis species. As a consequence, Germany can produce PDO wines with these varieties, while in other countries (like Italy and France) the article 93 of the Reg. $1308 / 2013$ is applied, which allows the use of varieties coming from "a cross between $V$. vinifera and other species of Vitis genus" only for table and GPI wines. Also in Austria some varieties (Muscaris, Souvignier gris, Bluetenmuskateller, Rathay, Roesler) are classified as $V$. vinifera.

Recently the EU Commission, by the Implementing Regulation 2018/606 of 19 April 2018, allowed the protection of PDO Dons wines (Denmark), that can also be obtained from Cabernet Cortis, Orion, Solaris, Rondo and Regent (resistant varieties selected in Germany). The Commission has pinpointed the contradiction with the aforementioned article 93 of Reg. 1308/2013 stating that "there is no reference list nor scientific document available from any official competent body, such as OIV, which currently would allow to undisputedly categorize $V$. vinifera species or a cross between $V$. vinifera and other Vitis species, neither to distinguish between them". As a consequence, the Commission decided that this issue is under national responsibility.

This position of EU Commission is puzzling, but most likely this is a step forward to allow the cultivation of disease resistant varieties also for PDO wine production in the future. In the next review of the wine $\mathrm{CMO}$
(Common Market Organisation), probably clearer provisions will be laid down on this topic.

\section{New breeding techniques ( $\mathrm{Nbt}$ )}

Promising methods to quickly obtain disease resistant vines, while keeping unaffected the rest of the traits, were recently made available. The most powerful is gene editing like CRISPR/Cas which requires the knowledge of nucleotide sequence and function of the target site. Traditional wine grape varieties with different edits of known targets can be produced in a single step and selected for advanced trials based on phenotypic traits [14]. This target can be reached thanks to the great progress of the" -omics" sciences which include the big data management [15].

\section{Perspectives}

The most important aspects of traditional breeding (controlled inter-specific hybridization for wine grapes) to be emphasized are as follows:

- care on wine quality (besides durable resistance) and this is a lesson learned from the past.

- need to develop local breeding programs (involving all native varieties).

- need to explore all Vitis world germplasm, including Near East and Caucasian V. vinifera varieties.

- need to address more diseases/pests.

- need to preserve previous biodiversity (inter- and intra-varietal variability) because today's diversity may include resistance to diseases considered unimportant or currently unknown.

- need of a national network to assess the agronomical behaviour of the new varieties all over the territory (like the OSCAR network in France).

On the other hand, the most important aspects of the new breeding techniques (Nbt) for wine grapes to be emphasized are as follows:

- science has to take its course, solving current problems (regeneration, side effects) and reaching the target; the edited resistant vines will be a new tool to be considered by policymakers to cope with sustainability.

- choice for utilization of edited resistant grape varieties (when available and where allowed) will be based on political/commercial aspects (best advantage for the national wine chains).

The ampelographic platform of a given area will be modified in the case new varieties (from traditional breeding) are utilized, with problems with PDO wine production; on the other hand no modifications occur in the case of edited varieties, because they will be most likely considered as clones. 


\section{Conclusion}

Under this context the role of the scientist is as follows:

- Science side: to guarantee excellent organoleptic wine traits together with the best level of durable resistance and to improve resilience of the wine system in a broader way.

- Society side: to recognize that this innovation has to be shared with and accepted by the other actors of the wine chain (including the consumers); the role of education becomes crucial and in order to be effective a commitment of resources and time is needed.

- Culture side: to emphasize the wine drinking as a cultural fact and a way of life.

\section{References}

1. J.W. Erisman, G. Brasseur, P. Ciais, N. van Eekeren, T.L. Theis. Nature, 519, 151-153 (2015).

2. H.P. Olmo. Vinifera Rotundifolia hybrids as wine grapes. Am. J. Enol. Vitic., 22, 87-91 (1971).

3. T.V. Munson. Foundations of American Grape Culture. T.V. Munson \& Son, Denison, Texas, pp. 252 (1909).

4. P. Galet. Cépages et vignobles de France. Tome 1. Les vignes américaines. Impr. Ch.Déhan, Montpellier, pp. 554 (1988).

5. J.M. Boursiquot. Prog. Agric. Vitic., 107, 15-20 (1990).

6. G. Alleweldt. The breeding of fungus- and phylloxera-resistant grapevine varieties., Proc. 3rd Int. Symp. Grape Breeding, Davis (California), 242250 (1980).

7. A. Bouquet. Vitis $x$ Muscadinia hybridization: A new way in grape breeding for disease resistance in France. In Proceedings for the 3rd International. Symposium on Grape Breeding, 15-18 June 1980, Davis, California, US (1980).

8. P.Ia. Golodriga. Culture de variétés de vigne polyrésistantes. Génétique et amélioration de la vigne. In IIe Symposium International sur l'Amélioration de la Vigne, 14-18 June 1977, Bordeaux, France (1978).

9. P. Kozma jr. Int. J. Hortic. Sci., 8, 41-46 ( 2002).

10. K. Anderson, S. Nelgen. Which Winegrapes Varieties are Grown where? A global empirical pictures (University of Adelaide Press, e-book, 2020).

11. L. Bavaresco. Vignevini, 6, 29-38 (1990).

12. A. Reynolds. Grapevine Breeding Programs for the Wine Industry (Woodhead Publishing, 2015).

13. L. Bavaresco. Acta Hortic. 1248, 7-13 (2019).

14. A. Scheben, D. Edwards. Science, 355, 1122-1123 (2017).

15. M. Baker. Nature, 494, 416-419 (2013). 